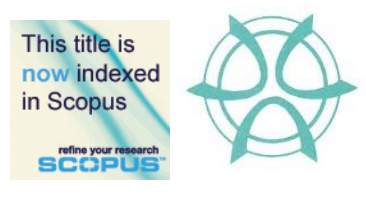

PLANNING MALAYSIA:

Journal of the Malaysian Institute of Planners

VOLUME 16 ISSUE 1 (2018), Page 50 - 62

\title{
THE IMPACT OF FREIGHT VEHICLE ACCESS RESTRICTION ON THE SUSTAINABILITY OF JAKARTA INTRA URBAN TOLLWAY SYSTEM
}

\author{
Nahry Yusuf ${ }^{1}$ \\ ${ }^{1}$ UNIVERSITY OF INDONESIA
}

\begin{abstract}
Freight vehicle access restriction policy in 2011 has had an impact on the performance of Jakarta Intra Urban Tollway (JIUT) system. The purpose of this study is to analyse the impact of the policy on Jakarta Intra Urban Toll way system before and after its implementation and to analyse the impact that occurs without the implementation of this policy by using the sustainable transportation indicators as the research parameters. The assessment results of the parameters (speed, amount of fuel consumption, cost of fuel consumption, fatality rate, cost of accident victim, amount of $\mathrm{CO}_{2}$ emissions, cost of carbon pollution, and noise level) indicate that freight vehicle access restriction policy has a positive impact on traffic smoothness and safety but does not support overall urban sustainable transportation in JIUT system. In addition, if the policy was not implemented, its impact would have been worse than the current condition. It implies that the implementation of the policy is a right decision though some parameters should be improved to attain sustainable transport system.
\end{abstract}

Keyword: Freight vehicle, access restriction, sustainable transportation, toll way system. 
PLANNING MALAYSIA

Journal of the Malaysia Institute of Planners (2018)

\section{INTRODUCTION}

Economic growth in a country is generally reflected in the increase on trade activities. Economic activities are closely linked to the city logistics system, where these activities involve moving goods from the point they were produced to the point they were consumed. The goods movements will inevitably come into contact with the city and are closely linked to truck trips.

The increase of truck traffic has a large impact on highway transportation in many cities. In congested cities, increased truck traffic worsens the delay, safety, energy use, and emissions. Local transport authority of some cities has proposed a number of strategies to overcome these problems, including combinations of infrastructure, regulatory, and economic mechanisms (Cherry \& Adelakun, 2012). From different viewpoint, Munuzuri, Larraneta, Onieva and Cortés (2005) classify the strategies into those related to public infrastructure, land use management, access conditions, traffic management, enforcement and promotion.

Restricting truck traffic to off-peak hours is one commonly used strategy in many cities all over the world, including in developing countries such as Bangkok, Thailand and Petaling Jaya, a major Malaysian city originally developed as a satellite township for Kuala Lumpur. Off-peak hour's delivery provides a methodology to remove truck traffic from the rush hour periods through a co-operative approach amongst road operators and the industry (Aschauera \& Starkl, 2010). From several studies, it was shown that this strategy has a positive impact on some of the parameters studied though most of the truck operators initially raise objection to the strategy due to the longer distance of the alternative route that they have to travel (Treerapongpichit, 2003; Mei \& Ruban, 2010). Aschauera \& Starkl (2010), who simulated trucks schedules, argue that off-peak hour's delivery has made more efficient use of road capacity, and capital expenditure for road construction can be avoided or at least postponed. Furthermore, the elimination of bottlenecks lead to competitive advantages for industry, business parks, and the entire urban area, and also benefits the environment. Qiu et al. (2015) prove that night time-only truck traffic regulation would produce less pavement distresses and better pavement performance due to the contribution of the lower temperature at night time.

In addition to research on the impact of off-peak hours delivery regulation, Dablanc (2007) studied the implementation of truck access restrictions based on environmental criteria in some northern European cities (Amsterdam, Copenhagen, Stockholm, Goteborg) and found that only newer trucks, or fully loaded trucks, are permitted to enter the city centre. These new standards tend to replace former weight and size restrictions, which are now considered quite irrelevant (Dablanc, 2007).

Even though this strategy has been adopted in many cities worldwide, it still needs supporting policies to foster the shifting of urban freight delivery 
Nahry Yusuf

The Impact of Freight Vehicle Access Restriction on The Sustainability of Jakarta Intra Urban Tollway System

traffic to the off-peak hours. Veras (2008) investigated some policies from the economic viewpoint and assess their effectiveness in competitive markets. Such policies seemed to be needed because the empirical evidence indicates that in urban freight competitive markets, freight road pricing may not be the most effective way to move truck traffic out of the congested hours. This is because the decision about delivery time is jointly made between the carriers and the receivers; the carriers have great difficulties passing toll costs to receivers; and, in the few cases where toll costs could be passed, the price signal reaching receivers is of no consequence compared to receivers' incremental costs of offpeak hour's deliveries. The result suggests the use of tax incentives to receivers willing to accept off-peak hours deliveries, combined with freight road pricing as a revenue generation mechanism.

Furthermore, off-peak hour's delivery usually comes up against the receivers, who are not willing to change how they receive their goods. Off-peak hour's deliveries and urban distribution centres policy in two Spanish cities (Barcelona and Santander) were studied to investigate the receivers' intention to adopt both policies (Domíngueza, Veras, Ibeasa, \& dell'Olioa, 2012). As the results, the receivers were more willing to adopt an urban distribution centre policy, especially in Barcelona, whose receivers opposed firmly off-peak hour's delivery. The incentives strongly influence receivers to adopt these policies; however, this influence is more significant in certain business sectors, such as food (for off-peak hour's delivery in Barcelona), restaurant and hotel, and furniture (for urban distribution centre in Santander and Barcelona, respectively).

From such previous studies it can be seen that though the access restriction strategy has had a positive impact on some parameters, the truck operators as main actors of city logistics were not in favour on it. Hence, we still have some problems to be solved before the optimal results to all stakeholders of city logistics, namely shippers, receivers, carriers, administrators, and consumers can be achieved (Taniguchi, 2001).

Jakarta, as the capital city of Indonesia, is experiencing brisk economic development, and this is indicated by the increased activity of truck trips, both trips within the city of Jakarta and the trips that just passing through the city of Jakarta. The access restriction policy for the trucks has been implemented on parts of the Jakarta Intra Urban Tollway (JIUT) system. JIUT is a ring road in the central of Jakarta, which connects the intercity highway from the south, east and west. Trucks are now prohibited to access the Cawang-Tomang-Pluit segment (statutory segment) from 05.00 am to $22.00 \mathrm{pm}$ (see Figure 1). The duration of the restriction is longer compared to the ones applied in Petaling Jaya and Bangkok (i.e. from about 06.30 to $09.30 \mathrm{am}$ ). The alternative segment for trucks movement during this access restriction time is Cawang-Tanjung Priok-Pluit segment of JIUT (advisory segment). As a result of this access restriction, this alternative segment suffered severe congestion at the time of restriction, while 
PLANNING MALAYSIA

Journal of the Malaysia Institute of Planners (2018)

the restricted access segment improved its speed performance. Thus, this policy needs to be evaluated whether this access restriction has a positive impact on JIUT as a unified system rather than each segment individually, i.e. both the restricted segment and the alternative one, especially with respect to the sustainability of the urban transport system. Evaluation is needed since JIUT is located in the central of Jakarta and becomes the main road connecting the movement of people and goods to/from east, west and south of Jakarta. The poor performance of traffic in this system will have a big effect on the wider transportation system, let alone JIUT is also the main access to/from the port of Tanjung Priok and Soekarno Hatta International Airport.

The purpose of this study is to analyse the impact of access restriction policy on JIUT system before and after its implementation and to analyse the impact with the absence of this policy.

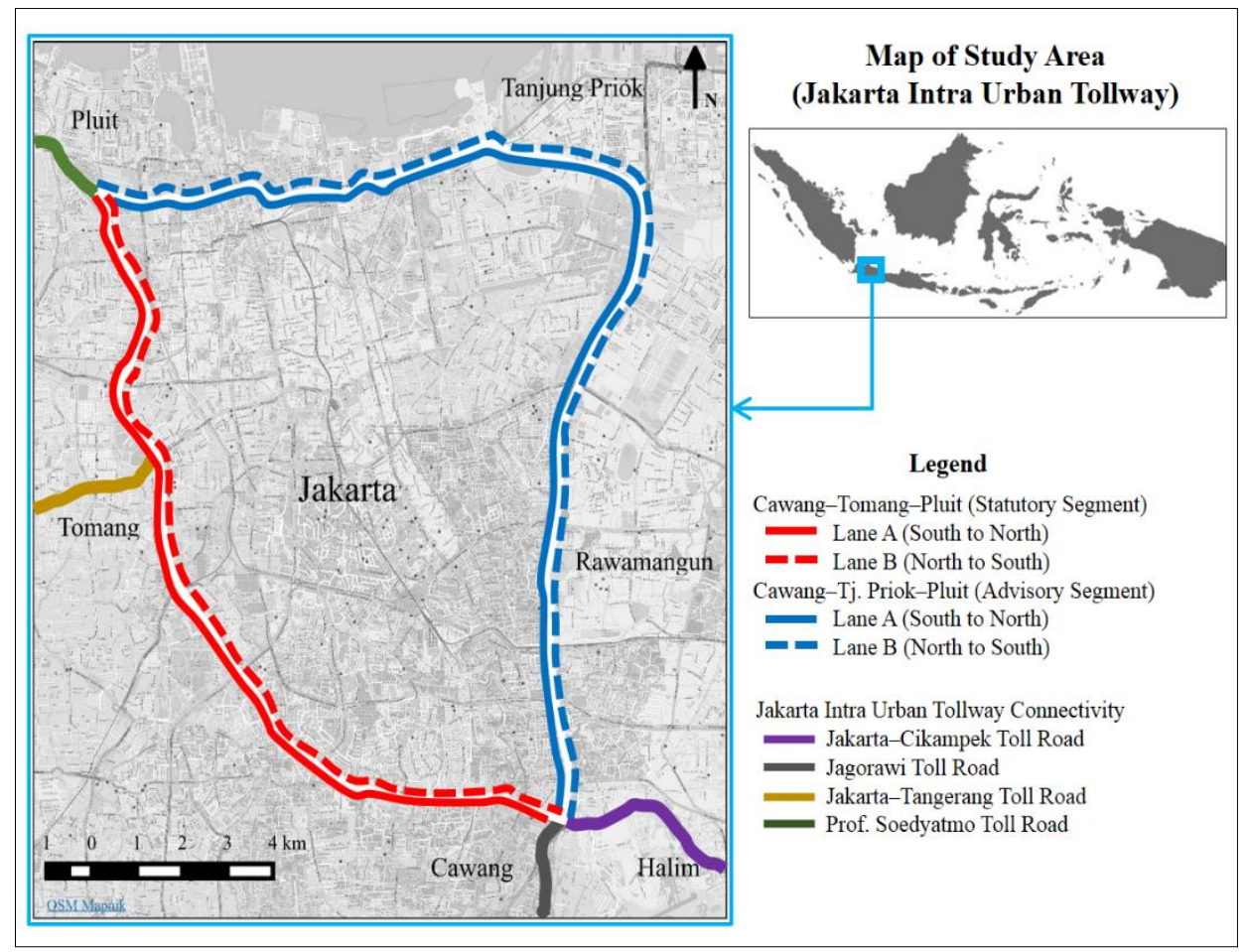

Figure 1: Jakarta Intra Urban Tollway System

\section{RESEARCH METHODOLOGY}

JIUT was the first ring road built in the central of Jakarta. It connects four neighbouring cities of Jakarta, namely Bogor and Depok (southern part), Tangerang (western part) and Bekasi (eastern part). On the north of Jakarta is 
Nahry Yusuf

The Impact of Freight Vehicle Access Restriction on The Sustainability of Jakarta Intra Urban Tollway System

Java Sea, where the sea port of Tanjung Priok is located and directly connected to JIUT. The Soekarno Hatta International Airport, which is located near Pluit area, is also connected directly to JIUT. Traffic from Bogor and Depok enter or pass through Jakarta through JIUT, and so do the ones that come from Tangerang and Bekasi. Due to the vital role of JIUT, the traffic load of this toll way has been increasing from time to time. The increased traffic has led to the implementation of truck access restriction in some parts of JIUT.

Access restriction on JIUT has been implemented since June, 2011 through the Regulation of Minister of Transportation No. 62, 2011. The restriction is applicable to the operational time of freight vehicles of 1.2 axle configuration or more in JIUT. This Regulation of the Minister was issued based on the foundation that in order to optimize the use and movement of traffic on the Jakarta Intra Urban Tollway, it was deemed necessary to regulate the freight traffic to ensure the safety, order and smoothness of traffic and road transport. Freight vehicles, except fuel-transporting trucks, are not allowed to pass Cawang-Tomang-Puit segments (as statutory segment) during 5.00 am to 10.00 $\mathrm{pm}$. During this restricted period, freight vehicles can use the alternative segment, which is the Cawang-Tanjung Priok-Pluit segment. This segment is named as advisory segment to indicate the transport authority provides this segment as an alternative segment and advises the freight vehicles to use it as a substitute to the statutory segment.

Even though the implementation of regulation has resulted in better performance of the statutory segment, i.e. in terms of vehicle speed, this is not the case for the advisory segment. Hence, this study aims to evaluate the impact of the regulation on the JIUT system as a whole system, by looking at the parameters that could represent the sustainability of the system, and not just vehicle speed.

Sustainable transportation should provide resources for a safe and satisfying future for all people in a society that is just caring for the basic human needs. The main factors affecting passenger transport are physical, psychological, and social needs, but goods transport is affected by market forces and government policies (Richardson, 2005). While there is no standard definition for sustainable transport system, some of the definitions adopted reflect that sustainable transport system must be effective and efficient in providing safe and fair access to basic economic and social services, promoting economic development and supporting environmental integrity (Jeon, Amekudzi, \&Vanegas, 2006). In this context, development must be characterized by the definition of economic, environmental, and social sustainability (Russo \& Comi, 2011).

Based on this concept, this study evaluates the sustainability of transport system on JUT based on the following parameters: speed and the amount of fuel consumption (as economic indicators); fatality rate (as social indicators); and $\mathrm{CO}_{2}$ emissions and noise level (as environmental indicators). To integrate these 
parameters the cost parameters were used, which include fuel consumption costs, the costs of accident victims and the costs of carbon pollution.

Since the policy was implemented beginning June 2011, its impact was illustrated in terms of changes in the magnitude of these parameters before and after implementation (represented by 2010, 2011, and 2012), as well as the differences of the magnitudes between the conditions after policy implementation (represented by 2011 and 2012) and the conditions if the policy is not applied (with and without regulation) for the same years. The analysis was limited to impact up to 2012 in order to preclude the impact of other specific activities of the city which may also contribute to those parameters. Each parameter was calculated for the statutory segment and advisory segment, as well as a combination of both. The latter was to describe the overall performance of the JIUT system, while the former ones to describe the performance of each segment.

The data used in this study was obtained from the operator of JIUT system, PT Jasa Marga (Persero) Tbk and PT Citra Marga Nusaphala Persada Tbk. They include data such as road length and gradient, the average speed, road capacity, traffic volume, the number of accidents and accident victims. The analysis of the fuel consumption and its associated cost was based on the Indonesian Guidelines for Calculation of Vehicle Operating Cost (Ministry of Public Works, 2005a) and the Indonesian Highway Capacity Manual (Directorate General of Highways, 1997). The cost of casualty victims was calculated based on the Indonesian Guidelines for Calculation of Traffic Accident Cost by Using The Gross Output Method (Human Capital) (Ministry of Public Works, 2005b), $\mathrm{CO}_{2}$ emissions based on the Indonesian Guidelines for the Methodology for Calculating Greenhouse Gas Emissions, Procurement and Use of Energy (Ministry of Environment, 2012), and the noise level prediction uses the empirical equations adopted by Hajek and Krawczyniuk (1984).

The analysis was mainly based on the vehicle volume of both segments according to the vehicle classifications, namely light vehicle, medium heavy vehicle and large truck. The analysis of fuel consumption was based on the empirical model that involved main variables such as road gradient, speed and acceleration rate, and vehicle weight. The resulting fuel consumption measure was then converted into $\mathrm{CO}_{2}$ emission by applying $\mathrm{CO}_{2}$ conversion factor which depends on the fuel type of each vehicle class. For the fatality rate, the analysis involved the number of fatal accident, vehicle volume and road length. For noise level, the measure was represented by the equivalent energy level $\left(\mathrm{L}_{\mathrm{eq}}\right)$ within range of 30 meters from the edge of road pavement. The empirical model of $\mathrm{L}_{\mathrm{eq}}$ was based on vehicle volume and speed. Subsequently, the cost of each parameter, namely cost of fuel consumption, cost of accident, and cost of carbon pollution was derived by applying unit cost associated to each parameter, such as fuel price, unit cost of accident, and unit cost of carbon emission. 
Nahry Yusuf

The Impact of Freight Vehicle Access Restriction on The Sustainability of Jakarta Intra Urban Tollway System

To estimate the parameters for year 2011 and 2012 in case of the access restriction policy was not implemented, regression technique was applied to predict the input data of all the parameters calculation using data of 2008-2010. To produce a more accurate prediction, three types of regression (linear regression, logarithmic regression, and exponential regression) were then selected based on the largest coefficient of determinant $\left(\mathrm{R}^{2}\right)$. After the prediction of the parameter data was conducted, the transport parameter values were calculated using all the guidelines previously mentioned.

\section{RESULT AND DISCUSSION}

The results of data processing used for analysis of changes in sustainable transportation indicators on the JIUT system before and after the application of Regulation of Minister of Transportation No. 62, 2011 can be seen in Table 1. The result of data analysis was then used to analyse the changes in the sustainable transportation indicator on the JIUT system with and without the application of Regulation of Minister of Transportation No. 62, 2011 can be seen in Table 2.

\section{The Analysis of Before and After the Implementation of Policy}

From Table 1 it can be seen that there is an increase in the average travel speed at statutory segment in 2012 compared to 2010. This condition can occur due to a decrease in the number of freight vehicles passing through the statutory segment, given the characteristics of large trucks seen as slow-moving vehicles and impeding the movement of traffic, especially during peak hours. This indicates that the policy of access restrictions on of freight vehicles at statutory segment in 2011 has a positive impact on speed at statutory segment.

Table 1: Sustainable transport parameters before and after the implementation of Regulation of Minister of Transportation No. 62, 2011

\begin{tabular}{|c|c|c|c|c|c|c|}
\hline \multirow[b]{2}{*}{ Indicators } & \multirow[b]{2}{*}{ Parameters } & \multirow[b]{2}{*}{ Unit } & \multirow[b]{2}{*}{ Segment } & \multicolumn{3}{|c|}{ Year } \\
\hline & & & & $\begin{array}{c}2010 \\
\text { (Before) }\end{array}$ & $\begin{array}{c}2011 \\
\text { (Transition) }\end{array}$ & $\begin{array}{c}2012 \\
\text { (After) }\end{array}$ \\
\hline \multirow{4}{*}{ Economy } & Speed & $\mathrm{km} /$ hour & Statutory & 38.15 & 45.81 & 53.95 \\
\hline & \multirow{3}{*}{$\begin{array}{l}\text { Fuel } \\
\text { consumption }\end{array}$} & \multirow{3}{*}{$\begin{array}{l}\text { litre per } \\
\mathrm{km}\end{array}$} & Statutory & $323,188,276$ & $315,997,299$ & $322,804,306$ \\
\hline & & & Advisory & $323,426,063$ & $336,611,590$ & $362,094,326$ \\
\hline & & & JIUT system & $646,614,339$ & $652,608,889$ & $684,898,631$ \\
\hline \multirow{3}{*}{ Social } & \multirow{3}{*}{ Fatality rate } & \multirow{3}{*}{$\begin{array}{l}\text { fatality } \\
\text { per } 100 \\
\text { million } \\
\text { veh.km }\end{array}$} & Statutory & 0.34 & 0.20 & 0.26 \\
\hline & & & Advisory & 0.13 & 0.12 & 0.12 \\
\hline & & & JIUT system & 0.12 & 0.08 & 0.10 \\
\hline \multirow{6}{*}{ Environment } & \multirow{3}{*}{$\mathrm{CO}_{2}$ emission } & \multirow{3}{*}{$\begin{array}{l}\text { kg per } \\
\text { year }\end{array}$} & Statutory & $775,731,358$ & $750,196,244$ & $758,506,929$ \\
\hline & & & Advisory & $774,702,75$ & $809,795,031$ & $876,271,867$ \\
\hline & & & JIUT system & $1,550,434,111$ & $1,559,991,276$ & $1.634,778,796$ \\
\hline & \multirow{3}{*}{ Noise level } & \multirow{3}{*}{$\mathrm{dBA}$} & Statutory & 74.17 & 74.89 & 75.64 \\
\hline & & & Advisory & 73.51 & 75.03 & 76.55 \\
\hline & & & JIUT system & 77.19 & 78.30 & 79.46 \\
\hline
\end{tabular}


PLANNING MALAYSIA

Journal of the Malaysia Institute of Planners (2018)

\begin{tabular}{|c|c|c|c|c|c|c|}
\hline \multirow{3}{*}{ Integration } & \multirow{3}{*}{$\begin{array}{l}\text { Cost of fuel } \\
\text { consumption, } \\
\text { Cost of } \\
\text { accident victim, } \\
\text { Cost of carbon } \\
\text { pollution. }\end{array}$} & \multirow{3}{*}{ rupiah } & Statutory & $1,531,370,394,967$ & $1,495,624,789,954$ & $1,534,610,085,078$ \\
\hline & & & Advisory & $1,530,788,472,292$ & $1,593,258,428,128$ & $1,722,108,708,745$ \\
\hline & & & JIUT system & $3,062,158,867,259$ & $3,088,883,218,082$ & $3,256,718,793,823$ \\
\hline
\end{tabular}

Table 2: Sustainable transport parameters with and without the implementation of Regulation of Minister of Transportation No. 62, 2011

\begin{tabular}{|c|c|c|c|c|c|c|c|}
\hline \multirow{2}{*}{ Indicators } & \multirow{2}{*}{ Parameters } & \multirow{2}{*}{ Unit } & \multirow{2}{*}{ Segment } & \multicolumn{2}{|c|}{ With Policy } & \multicolumn{2}{|c|}{ Without Policy } \\
\hline & & & & 2011 & 2012 & 2011 & 2012 \\
\hline \multirow{3}{*}{ Economy } & \multirow{3}{*}{$\begin{array}{l}\text { Fuel } \\
\text { consumption }\end{array}$} & \multirow{3}{*}{$\begin{array}{l}\text { litre per } \\
\mathrm{km}\end{array}$} & Statutory & $315,997,299$ & $322,804,306$ & $326,079,338$ & $334,988,834$ \\
\hline & & & Advisory & $336,611,590$ & $362,094,325$ & $334,650,841$ & $358,523,516$ \\
\hline & & & $\begin{array}{l}\text { JIUT } \\
\text { system }\end{array}$ & $652,608,889$ & $684,898,631$ & $660,730,179$ & $693,512,350$ \\
\hline \multirow{3}{*}{ `Social } & \multirow{3}{*}{ Fatality rate } & \multirow{3}{*}{$\begin{array}{l}\text { fatality } \\
\text { per } 100 \\
\text { million } \\
\text { veh.km }\end{array}$} & Statutory & 0.20 & 0.26 & 0.42 & 0.08 \\
\hline & & & Advisory & 0.12 & 0.12 & 0.40 & 0.08 \\
\hline & & & $\begin{array}{l}\text { JIUT } \\
\text { system }\end{array}$ & 0.08 & 0.10 & 0.20 & 0.04 \\
\hline \multirow{3}{*}{ Environment } & \multirow{3}{*}{$\mathrm{CO}_{2}$ emission } & \multirow{3}{*}{$\begin{array}{l}\mathrm{kg} \text { per } \\
\text { year }\end{array}$} & Statutory & $750,196,244$ & $758,506,929$ & $783,062,560$ & $804,897,406$ \\
\hline & & & Advisory & $809,795,031$ & $876,271,867$ & $801,310,753$ & $859,439,557$ \\
\hline & & & $\begin{array}{l}\text { JIUT } \\
\text { system }\end{array}$ & $1,559,991,276$ & $1,634,778,796$ & $1,584,373,312$ & $1,664,336,962$ \\
\hline \multirow{3}{*}{ Integration } & \multirow{3}{*}{$\begin{array}{l}\text { Cost of fuel } \\
\text { consumption, } \\
\text { Cost of } \\
\text { accident victim, } \\
\text { Cost of carbon } \\
\text { pollution }\end{array}$} & \multirow{3}{*}{ rupiah } & Statutory & $\begin{array}{c}1,495,624,78 \\
9,954\end{array}$ & $\begin{array}{c}1,534,610,08 \\
5,078\end{array}$ & $\begin{array}{c}1,545,701,75 \\
8,738\end{array}$ & $\begin{array}{c}1,595,368,46 \\
8,966\end{array}$ \\
\hline & & & Advisory & $\begin{array}{c}1,593,258,42 \\
8,128\end{array}$ & $\begin{array}{c}1,722,108,70 \\
8,745\end{array}$ & $\begin{array}{c}1,583,761,95 \\
6,816\end{array}$ & $\begin{array}{c}1,704,205,89 \\
2,028\end{array}$ \\
\hline & & & $\begin{array}{l}\text { JIUT } \\
\text { system }\end{array}$ & $\begin{array}{c}3,088,883,21 \\
8,082\end{array}$ & $\begin{array}{c}3,256,718,79 \\
3,823\end{array}$ & $\begin{array}{c}3,129,463,71 \\
5,554\end{array}$ & $\begin{array}{c}3,299,574,36 \\
0,994\end{array}$ \\
\hline
\end{tabular}

From Table 1 it can be seen that the amount of fuel consumption has decreased by $0.1 \%$ at statutory segment in 2012 when compared to 2010 . While the amount of fuel consumption has increased by $12 \%$ at advisory segment and an increase of $5.9 \%$ in total JIUT system in 2012 when compared to 2010. The increase of fuel consumption on JIUT system can be caused by the change of vehicle composition that passes JIUT after the application of PM 62 Year 2011, that is the number of II-V class vehicles (truck with $\geq 2$ axles), which using the statutory segment has decreased after the application of policy and gives effect to the increasing number of vehicles of this type that use advisory segment, while the number of Class I vehicles (passenger vehicles) using the statutory segment has increased after the application of policy. Overall, the access restriction has had a negative impact on the amount of fuel consumption on the JIUT system.

In terms of fatality rate, Table 1 shows that the fatality rate has decreased by $22.5 \%$ at statutory segment, decreased by $4.8 \%$ at advisory segment, and decreased by $16.8 \%$ at total JIUT system in 2012 when compared to 2010 . This 
Nahry Yusuf

The Impact of Freight Vehicle Access Restriction on The Sustainability of Jakarta Intra Urban Tollway System

condition may be caused by the changes in the composition of vehicles passing through the JIUT as described previously. In addition, one of the other factors that could affect the condition of the decreasing accident rate is the establishment of the National Road Safety General Plan in 2011 which has a mission to make road safety a national priority. Overall, the policy has had a positive impact on the level of fatality on the JIUT system.

The analysis of $\mathrm{CO}_{2}$ emission shows that the $\mathrm{CO}_{2}$ emissions has decreased by $2.2 \%$ at statutory segment in 2012 when compared to the year 2010 . While the amount of $\mathrm{CO}_{2}$ emissions increased by $13.1 \%$ in the advisory segment and an increase of $5.4 \%$ in the total JIUT system in 2012 when compared to 2010. An increase in $\mathrm{CO}_{2}$ emissions in the total JIUT system could be due to changes in the amount of vehicle composition in accordance with the explanation in the previous analysis of fuel consumption parameter. This is also due to the amount of $\mathrm{CO}_{2}$ emissions direct relationship to the amount of fuel consumption. Overall, the policy has had a negative impact on the amount of $\mathrm{CO}_{2}$ emissions on JIUT system.

Analysis of noise level parameter in safe noisy area shows 2\% increase in noise level at statutory segment, $4.1 \%$ increase at advisory segment, and an increase of $2.9 \%$ in overall JIUT system in 2012 when compared to 2010. Safe noisy area is an area of 30 meters wide from the edge of the road pavement that has noise levels of less than 65 dBA (Ministry of Public Works, 2004). From Table 1 it can be seen that the noise level at statutory segment, advisory segment, and the total JIUT system in 2010-2012 are always above the recommended value of $65 \mathrm{dBA}$. Overall, the policy of limiting the access of freight vehicles at statutory segment in 2011 has had a negative impact on the noise level on the JIUT system.

Analysis of the combined parameters of the cost of fuel consumption, casualty costs, and carbon pollution costs (integrated cost indicator) shows an increase by $2 \%$ at statutory segment, an increase of $4.1 \%$ at advisory segment, and an increase of $2.9 \%$ in the total JIUT system in 2012 when compared to 2010. Overall, the policy has negatively impacted the overall sustainable transport indicators represented by the integrated cost of each indicator (economic, social, and environment), namely the cost of fuel consumption, the cost of casualties, and the cost of carbon pollution on the JIUT system.

\section{The Analysis of With and Without the Implementation of Access Restriction Policy}

From Table 2 it can be seen that the amount of fuel consumption at advisory segment due the application of policy was at $0.6 \%$ greater in 2011 and at $1 \%$ greater in 2012 compared to without the application of the policy. While the amount of fuel consumption with the application of the policy at statutory segment was $3.1 \%$ lesser in 2011 and $3.6 \%$ lesser in 2012, as well as $1.2 \%$ lesser 
PLANNING MALAYSIA

Journal of the Malaysia Institute of Planners (2018)

in total JIUT system in 2011 and 2012 compared to without the application of the policy. In other words, the application of the policy has an impact on the increase of fuel consumption at advisory segment and affects the decrease of the amount of fuel consumption at statutory segment and the total JIUT system compared to without application of policy. Overall, the implementation of the policy in 2011 has had positive impact on total fuel consumption than if the policy was not implemented.

The analysis on the fatality rate (social indicator) was conducted by taking into account the percentage change of fatality rate in the JIUT system with and without the application of policy. From Table 2 it can be seen that the fatality rate at statutory segment with the application of policy is $51.8 \%$ smaller in 2011 and $220.5 \%$ greater in 2012 than the absence of policy. The fatality rate at advisory segment with the application of the policy was $69.4 \%$ smaller in 2011 and $57.4 \%$ greater in 2012 compared to the absence of policy. The fatality rate in total JIUT system was $60.4 \%$ smaller in 2011 and $144 \%$ greater in 2012 compared to the absence of policy. In other words, the application of the policy has reduced the fatality rate in JIUT system in 2011, but increased in the following year. Overall, the implementation of the policy in 2011 has had a negative impact on the fatality rate than if the policy was not implemented.

Furthermore, the assessment on before and after changes in the parameters of sustainable transport indicators to the overall JIUT system can be seen in Table 3.

Table 3: "Before and after" assessment on sustainable transport indicator due to the implementation of Regulation of Minister of Transportation No. 62, 2011

\begin{tabular}{|c|c|c|c|c|}
\hline Indicators & Parameters & Impact & Segment & $\begin{array}{c}\text { Percentage Change } \\
\text { (Parameters of } 2012 \text { compared to } \\
\text { the ones of } 2010 \text { ) }\end{array}$ \\
\hline \multirow{4}{*}{ 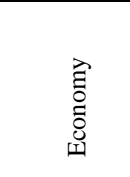 } & Speed & Positive & Statutory & $\begin{array}{c}\text { Increased }(41.3 \%) \\
\text { or } 53.95 \mathrm{~km} / \mathrm{hr}\end{array}$ \\
\hline & \multirow{3}{*}{ Fuel consumption } & \multirow{3}{*}{ Negative } & Statutory & Decreased $(0.1 \%)$ \\
\hline & & & Advisory & Increased $(12.0 \%)$ \\
\hline & & & JIUT system & Increased $(5.9 \%)$ \\
\hline \multirow{3}{*}{$\begin{array}{l}\text {. } \\
\text {. } \\
\text { in }\end{array}$} & \multirow{3}{*}{ Fatality rate } & \multirow{3}{*}{ Positive } & Statutory & Decreased $(22.5 \%)$ \\
\hline & & & Advisory & Decreased (4.8\%) \\
\hline & & & JIUT system & Decreased $(16.8 \%)$ \\
\hline \multirow{6}{*}{ 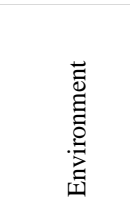 } & \multirow{3}{*}{$\mathrm{CO}_{2}$ emission } & \multirow{3}{*}{ Negative } & Statutory & Decreased $(2.2 \%)$ \\
\hline & & & Advisory & Increased (13.1\%) \\
\hline & & & JIUT system & Increased (5.4\%) \\
\hline & \multirow{3}{*}{ Noise level } & \multirow{3}{*}{ Negative } & Statutory & Increased $(2.0 \%)$ \\
\hline & & & Advisory & Increased $(4.1 \%)$ \\
\hline & & & JIUT system & Increased $(2.9 \%)$ \\
\hline \multirow{2}{*}{ 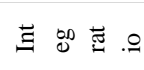 } & & \multirow{2}{*}{ Negative } & Statutory & Increased $(0.2 \%)$ \\
\hline & & & Advisory & Increased $(12.5 \%)$ \\
\hline
\end{tabular}


Nahry Yusuf

The Impact of Freight Vehicle Access Restriction on The Sustainability of Jakarta Intra Urban Tollway System

\author{
Cost of fuel consumption, \\ cost of accident victim, cost JIUT system Increased (6.4\%) \\ of carbon pollution
}

The analysis of $\mathrm{CO}_{2}$ emission shows that the $\mathrm{CO}_{2}$ emissions at the advisory segment with the application of the policy was $1.1 \%$ higher in 2011 and $2 \%$ higher in 2012 compared to the absence of policy. While the amount of $\mathrm{CO}_{2}$ emissions at statutory segment with the application of policy is $4.2 \%$ smaller in 2011 and 5.8\% smaller in 2012 and in the total JIUT system is $1.5 \%$ smaller in 2011 and $1.8 \%$ smaller in 2012 compared to the absence of policy. In other words, the application of policy has had an impact on the increase of $\mathrm{CO}_{2}$ emissions at advisory segment in 2011 and 2012 but decrease of $\mathrm{CO}_{2}$ emissions at statutory segment and total JIUT system in 2011 and 2012 compared to without application of policy. Overall, the implementation of access restriction policy in 2011 has had a positive impact on the amount of $\mathrm{CO}_{2}$ emissions compared to if the policy was not implemented.

Analysis on the combined parameters of fuel consumption costs, casualty costs, and carbon pollution costs (integrated cost indicator) shows that the integrated cost at advisory segment with the application of the policy was $0.6 \%$ larger in 2011 and $1.1 \%$ larger in 2012 compared to without application of the policy. However, the integrated cost indictor at statutory segment with the application of policy was $3.2 \%$ smaller in $2011,3.8 \%$ smaller in 2012 , and $1.3 \%$ smaller on the total system JIUT in 2011 and 2012 compared to without application of the policy. In other words, the application of the policy has had an impact on the increase of integrated cost indicator at advisory segment in 2011 and 2012 but has an impact on the decrease of such indicator at statutory segment and total system of JIUT in 2011 and 2012 compared to without the application of the policy. Overall, the implementation of the access restriction policy has had a more positive impact on the overall sustainable transport indicators as represented by the integrated cost of each indicator (economic, social and environmental) i.e cost of fuel consumption, cost of accident victim, and cost of carbon pollution on the total JIUT system compared to without the implementation of the policy.

The comparison of the sustainable transport indicators, namely with the application and without the application of the policy, in 2011 and 2012 is shown in Table 4.

Table 4: "With and without" assessment on sustainable transport indicator due to the implementation of Regulation of Minister of Transportation No. 62, 2011

\begin{tabular}{lll}
\hline Indicators Parameters $\quad$ Impact $\quad$ Segment & $\begin{array}{l}\text { Percentage Change } \\
\text { (Parameters of "with implementation" } \\
\text { compared to ones of "without } \\
\text { implementation" }\end{array}$ \\
\hline 2011 & 2012 \\
\hline
\end{tabular}


PLANNING MALAYSIA

Journal of the Malaysia Institute of Planners (2018)

\begin{tabular}{|c|c|c|c|c|c|}
\hline \multirow{3}{*}{ 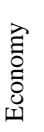 } & \multirow{3}{*}{ Fuel consumption } & \multirow{3}{*}{ Positive } & Statutory & Smaller $(3.1 \%)$ & Smaller $(3.6 \%)$ \\
\hline & & & Advisory & Greater $(0.6 \%)$ & Greater $(1.0 \%)$ \\
\hline & & & JIUT system & Smaller (1.2\%) & Smaller $(1.2 \%)$ \\
\hline \multirow{3}{*}{ 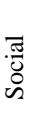 } & \multirow{3}{*}{ Fatality rate } & \multirow{3}{*}{ Negative } & Statutory & Smaller $(51.8 \%)$ & Greater $(220.5 \%)$ \\
\hline & & & Advisory & Smaller (69.4\%) & Greater $(57.4 \%)$ \\
\hline & & & JIUT system & Smaller $(60.4 \%)$ & Greater $(144.0 \%)$ \\
\hline \multirow{2}{*}{ 离 } & \multirow[b]{2}{*}{$\mathrm{CO}_{2}$ emission } & \multirow[b]{2}{*}{ Positive } & $\begin{array}{l}\text { Statutory } \\
\text { Advisory }\end{array}$ & $\begin{array}{l}\text { Smaller }(4.2 \%) \\
\text { Greater }(1.1 \%)\end{array}$ & $\begin{array}{l}\text { Smaller }(5.8 \%) \\
\text { Greater }(2.0 \%)\end{array}$ \\
\hline & & & JIUT system & Smaller (1.5\%) & Smaller $(1.8 \%)$ \\
\hline \multirow{3}{*}{ 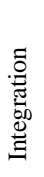 } & \multirow{3}{*}{$\begin{array}{l}\text { Cost of fuel } \\
\text { consumption, } \\
\text { cost of accident } \\
\text { victim, } \\
\text { cost of carbon } \\
\text { pollution }\end{array}$} & \multirow{3}{*}{ Positive } & Statutory & Smaller $(3.2 \%)$ & Smaller $(3.8 \%)$ \\
\hline & & & Advisory & Greater $(0.6 \%)$ & Greater $(1.1 \%)$ \\
\hline & & & JIUT system & Smaller (1.3\%) & Smaller $(1.3 \%)$ \\
\hline
\end{tabular}

\section{CONCLUSION}

Based on the trend of changes in sustainable transport indicators associated to the implementation of freight vehicle access restriction policy on JIUT, it can be concluded that the policy has had a positive impact on traffic smoothness and safety but it has not supported the overall urban sustainable transportation in JIUT system. Nevertheless, if the policy was not implemented, the situation would have been worse than the current condition. This implies that the implementation of the policy was a right decision though further efforts must be taken to improve some of the parameters in order to attain sustainable transport system. Moreover, the regulator should also consider the other sustainable transport indicators rather than only the travel time as a single determinant.

\section{ACKNOWLEDGEMENT}

This research was supported by research funds made available through the National Strategic Research Scheme of Directorate General of Research Strengthening and Development of Ministry of Research, Technology and Higher Education of Indonesia.

\section{REFERENCES}

Aschauera, G. J., \& Starkl, F. (2010). Time4trucks - cooperative time regulation of road freight transportation in urban areas for reducing bottlenecks. Procedia Social and Behavioral Sciences, 2, 6242-6250.

Cherry, C. R., \& Adelakun, A. A. (2012). Truck driver perceptions and preferences: Congestion and conflict, managed lanes, and tolls. Transport Policy, 24, 1-9.

Dablanc, L (2007). Goods transport in large European cities: difficult to organize, difficult to modernize. Transportation Research Part A: Policy and Practice, 41, 280285. 
Nahry Yusuf

The Impact of Freight Vehicle Access Restriction on The Sustainability of Jakarta Intra Urban Tollway System

Directorate General of Highways. (1997). Indonesia Highway Capacity Manual.

Domíngueza, A., Veras, J. H., Ibeasa, A., \& dell'Olioa, L. (2012). Receivers' response to new urban freight policie. Procedia-Social and Behavioral Sciences, 54, 886896.

Hajek, J. J., \& Krawczyniuk, R. (1984). The accuracy of highway traffic noise predictions. Canadians Acoustics, 12(2), 29-38.

Jeon, S. W., Amekudzi, A. A., \& Vanegas, V. (2006). Transportation system sustainability issues in high-, middle-, and low-income economies: Case studies from Georgia (U.S.), South Korea, Colombia, and Ghana. Journal of Urban Planning and Development, 132(3).

Mei, W. P. and Ruban, A. (August 4, 2010). Heavy vehicles banned from three NSE stretches during peak hours. http://pajpbm.com/ban-on-heavy-vehicles-duringpeak-hours.html.

Ministry of Environment. (2012). Methodology for calculating greenhouse gas emissions, procurement and use of energy. Guidelines for the Implementation of National Greenhouse Gas Inventory. Book II vol. 1.

Ministry of Public Works. (2005a). Calculation of vehicle operating costs part i: unpaid costs (running cost). Construction and Building Guidelines Number: Pd T-152005-B.

Ministry of Public Works. (2005b). Calculation of traffic accident amount by using the gross output method (human capital). Construction and Building Guidelines Number: Pd T-02-2005-B.

Ministry of Public Works (DPU). (2004). Noise prediction due to traffic. Construction and Building Guidelines Number: Pd T-10-2004-B.

Munuzuri, J., Larraneta, J., Onieva, L., \& Cortés, P. (2005). Solutions applicable by local administrations for urban logistics improvement, Cities, 22(1), 15-28.

Qiu, S., Xiao, D. X., Wang, K. C. P., Wang, W., \& Moravec, M. M. (2015). Impacts of nighttime-only truck traffic regulation on pavement performance. Journal of Infrastructure System, 21(1).

Richardson, B. C. (2005). Sustainable transport: Analysis framework. Journal of Transport Geography, 13, 29-29.

Russo, F., \& Comi, A. (2011). Measures for sustainable freight transportation at urban scale: expected goals and tested results in Europe. Journal of Urban Planning and Development, 137(2), 142-152.

Taniguchi, E. (2001). City logistics: Network modelling and intelligent transport systems. Elsevier Science.

Treerapongpichit, B. (2003, April 5). Thailand transport minister is firm on truck ban. Bangkok Post. Retrieved from https://www.highbeam.com/doc/1G1122343524.html.

Veras, J. H. (2008). Necessary conditions for off-hour deliveries and the effectiveness of urban freight road pricing and alternative financial policies in competitive markets. Transportation Research Part A, 42, 392-413. 